\title{
THE EFFECT OF Cr INTERLAYER ON THE CRYSTAL STRUCTURE AND CORROSION RESISTANCE OF CrN COATING ON STEEL
}

\author{
Dinh Thi Mong Cam, Nguyen Thanh Phuong, Nguyen The Quyen, \\ Nguyen Huu Chi, Le Khac Binh, Tran Tuan, Duong Ai Phuong, Nguyen Chi Lang \\ University of Sciences, VNU-HCM
}

\begin{abstract}
In this study, chromium nitride ( $\mathrm{CrN}$ ) hard coatings on stainless steel substrates with chromium (Cr) interlayers incorporated between the coatings and the steel substrates in order to improve adhesion of the coatings are investigated. $\mathrm{Cr}$ layers are prepared using d.c magnetron sputtering, and then $\mathrm{CrN}$ coatings are prepared using reactive d.c magnetron sputtering on these $\mathrm{Cr}$ layers. The effect of the $\mathrm{Cr}$ layer on the crystal structure and corrosion resistance of the $\mathrm{CrN}$ coating through surface modification is determined. The results show that regardless of whether the coatings include the Cr layers, face centered cubic structure of $\mathrm{CrN}$ phase with the preferred orientation on (111) planes parallel to coating surface remains and grain size of the $\mathrm{CrN}$ does not change. Nevertheless, the $\mathrm{Cr}$ layer induces stronger the (111) peak, reduces the residual stress and increases corrosion resistance of the $\mathrm{CrN}$ coatings. In addition, corrosion resistance of $\mathrm{CrN}$ coatings with the $\mathrm{Cr}$ layers deposited at different substrate bias and deposition time is similar although (111) peak intensity and residual stress of them change. The crystal structure and protection ability of the $\mathrm{CrN} / \mathrm{Cr}$ coatings are optimum for $\mathrm{Cr}$ layers deposited with substrate bias of $-60 \mathrm{~V}$ and deposition time below 10min.
\end{abstract}

Keywords: Chromium nitride coatings, $\mathrm{CrN} / \mathrm{Cr}$ coatings, $\mathrm{CrN}$ coatings, reactive d.c magnetron sputtering.

\section{INTRODUCTION}

In recent years, the $\mathrm{CrN}$ coating has been identified as one of the most promising protective layers on surfaces of tools and dies thanks to its excellent mechanical properties and corrosion resistance. Nevertheless, the coatings deposited by physical vapor deposition sometimes exhibit poor adhesion because of the high internal stress [1]. The residual stress is generated in the coating due to the lattice mismatch between crystalline planes and the mismatch of the thermal contraction between the coating and the substrate [2]. The residual stress influences the mechanical properties of coated material. Besides, in aggressive environments, the major corrosion problem of the coated material is the defects in the coating, e.g. porosity, cracks, pinholes that are formed during the deposition process. These defects may form direct paths between the substrate and the exposed environment [3]. The application of a metallic intermediate layer between the substrate and coating helps to improve the adhesion, reduce the residual stress, limit the effect of the defects and increase the corrosion resistance of the substrate. Chen, Han, Chang et al [1-3, 6-7] have used a $\mathrm{Cr}$ interlayer to increase the corrosion and tribological resistance of the $\mathrm{CrN}$ coating. Electroplating technique is the conventional way of producing the $\mathrm{Cr}$ layers. However, the electroplating process adversely impacts the environment. Thus, sputter deposition is considered as an appropriate method to produce environmentally safe Cr layers.

The objective of this study is to investigate the effect of sputter-deposited $\mathrm{Cr}$ interlayers on the crystal structure and corrosion resistance of $\mathrm{CrN}$ coatings. Two sets of specimens are prepared: one has the $\mathrm{Cr}$ layer prepared by sputter deposition between the $\mathrm{CrN}$ film and the 
substrate, denoted $\mathrm{CrN} / \mathrm{Cr}$ and the other has the $\mathrm{CrN}$ layer directly deposited on the substrate, denoted $\mathrm{CrN}$. The corrosion resistance of $\mathrm{CrN} / \mathrm{Cr}$ is compared with that of $\mathrm{CrN}$ and bare steel by electrochemical method.

\section{EXPERIMENTAL}

\subsection{Coating deposition}

AISI 304 stainless steel $(18 \% \mathrm{Cr}, 9.0 \% \mathrm{Ni}, 2.6 \% \mathrm{C}, 70.4 \% \mathrm{Fe})$ was used as substrate in this study. The steel sheets of $1 \mathrm{~mm}$ of thicness were cut to an appropriate size of $20 \mathrm{~mm} \times 30$ $\mathrm{mm}$. Prior to the deposition process, the steel substrates were ultrasonically cleaned in 3 chemical solutions: sodium hydroxide, chromic anhydride and aceton, and the substrate were then cleaned by Ar plasma at a high substrate bias of $500 \mathrm{~V}$ for $30 \mathrm{mins}$.

The deposition was carried out using a $99.98 \%$ pure $\mathrm{Cr}$ target. The sputtering gas is a mixture of $99.999 \%$ pure $\mathrm{Ar}$ and $99.998 \%$ pure $\mathrm{N}_{2}$ gases. The target-to-substrate distance was held constantly at $45 \mathrm{~mm}$. During each experiment, the $\mathrm{Cr}$ target was first pre-sputtered under a 3 mtorr argon pressure at a deposition current of 1 A for 20 to 30 mins to remove any possible oxide layer. Immediately following the pre-sputtering process, the $\mathrm{Cr}$ interlayers were deposited by sputter deposition with different substrate bias and deposition time. Deposition pressure and current of $\mathrm{Cr}$ layers were kept constantly at $3 \mathrm{mtorr}$ and $0.5 \mathrm{~A}$, respectively. The $\mathrm{CrN}$ coatings are then deposited by reactive d.c. magnetron sputtering for 60 mins. All $\mathrm{CrN}$ coatings in this study are deposited under a total $\mathrm{Ar}+\mathrm{N}_{2}$ gas pressure of 7.5 mtorr $\left(\mathrm{N}_{2} / \mathrm{Ar}=\right.$ $3 / 2$ ) with a substrate bias of $-50 \mathrm{~V}$ and a deposition current of $1 \mathrm{~A}$. These optimal deposition conditions of the $\mathrm{CrN}$ coating were determined in our previous studies [4,5]. The deposition conditions and some of properties of the coatings are summarized in Table 1.

Table 1. Deposition conditions for coatings, grain size (D), residual stress $\left(\sigma_{f}\right)$, and corrosion potential $\left(\mathrm{E}_{\text {corr }}\right)$ of specimens obtained

\begin{tabular}{ccccccc}
\hline Sample & $\begin{array}{c}\text { Substrate bias } \\
{[\mathbf{V}]}\end{array}$ & $\begin{array}{c}\text { Deposition time } \\
{[\mathbf{m i n}]}\end{array}$ & $\begin{array}{c}\text { Preferred } \\
\text { orientation }\end{array}$ & $\begin{array}{c}\mathbf{D} \\
{[\mathbf{n m}]}\end{array}$ & $\begin{array}{c}\sigma_{\mathrm{f}} \\
{[\mathrm{GPa}]}\end{array}$ & $\begin{array}{c}\mathbf{E}_{\text {corr }} \\
{[\mathbf{V}]}\end{array}$ \\
\hline $\mathrm{Steel}$ & - & - & - & - & - & 0.58 \\
$\mathrm{CrN}$ & -50 & 60 & $\mathrm{CrN}(111)$ & 33.38 & -22.97 & 0.86 \\
$\mathrm{CrN} / \mathrm{Cr}-19$ & $-50 /-25$ & $60 / 30$ & $\mathrm{CrN}(111)$ & 32.05 & -17.00 & 0.97 \\
$\mathrm{CrN} / \mathrm{Cr}-20$ & $-50 /-50$ & $60 / 30$ & $\mathrm{CrN}(111)$ & 33.76 & -17.60 & 0.95 \\
$\mathrm{CrN} / \mathrm{Cr}-21$ & $-50 /-60$ & $60 / 30$ & $\mathrm{CrN}(111)$ & 35.94 & -14.62 & 0.96 \\
$\mathrm{CrN} / \mathrm{Cr}-22$ & $-50 /-80$ & $60 / 30$ & $\mathrm{CrN}(111)$ & 33.63 & -14.92 & 0.95 \\
$\mathrm{CrN} / \mathrm{Cr}-24$ & $-50 /-50$ & $60 / 20$ & $\mathrm{CrN}(111)$ & 36.34 & -19.10 & 0.97 \\
$\mathrm{CrN} / \mathrm{Cr}-25$ & $-50 /-50$ & $60 / 10$ & $\mathrm{CrN}(111)$ & 35.35 & -18.20 & 0.98 \\
$\mathrm{CrN} / \mathrm{Cr}-27$ & $-50 /-25$ & $60 / 10$ & $\mathrm{CrN}(111)$ & 32.85 & -19.69 & 0.97 \\
$\mathrm{CrN} / \mathrm{Cr}-28$ & $-50 /-25$ & $60 / 20$ & $\mathrm{CrN}(111)$ & 34.37 & -21.18 & 0.97 \\
\hline
\end{tabular}

\subsection{Coating characterization}

The phase and structure of $\mathrm{CrN}$ coatings with and without $\mathrm{Cr}$ layers were analyzed by $\mathrm{X}$ ray diffraction $(\mathrm{XRD})$ with $\mathrm{CuK}_{\alpha}$ radiation $(\lambda=0.154 \mathrm{~nm})$. The specimens are investigated using $\theta / 2 \theta$ diffraction mode ranging from $20^{\circ}$ to $60^{\circ}$. The crystal structure of the coatings is determined by comparing their angles and intensities of diffraction peaks with those reported 
from Joint Committee of Powder Diffraction Standards (JCPDS). Form XRD spectra, the residual stresses $\left(\sigma_{\mathrm{f}}\right)$ of coatings were calculated using the Stoney's equation:

$$
\sigma_{f}=-\frac{E\left(d-d_{o}\right)}{2 v d_{o}}
$$

where $v(0.28)$ is the Poisson's ratio; $E$ (400 GPa for (111) CrN) was Young's modulus; $d_{o}$ $\left(2.394 \mathrm{~A}^{\mathrm{o}}\right.$ for the (111) planes) is the stress free lattice spacing; $d$ is the strained lattice spacing of the coating.

The corrosion behavior of $\mathrm{CrN}$ coatings with and without $\mathrm{Cr}$ layers is investigated by cyclic polarization $(\mathrm{CP})$ method. This electrochemical technique is an accelerated method for determining the characteristic corrosion potential $E_{\text {corr }}$. $E_{\text {corr }}$ is evaluated by the cyclic polarization curves (current-potential curves) over a small potential range from - $0.5 \mathrm{~V} / \mathrm{sce}$ to 1 $\mathrm{V} / \mathrm{sce}$. Electrochemical measurements were carried out in a standard three-electrode cell with a saturated calomel reference electrode (sce). AISI 304 stainless steel, $\mathrm{CrN}$ and $\mathrm{CrN} / \mathrm{Cr}$ specimens are immersed in an aerated $3.5 \% \mathrm{NaCl}$ solution for corrosion tests.

\section{RESULTS AND DISCUSSION}

\subsection{Crystal structure and residual stress of coatings}

As mentioned earlier, $\mathrm{CrN}$ exists in different phases so there is a limited range of nitrogen concentration wherein stoichiometric phase of $\mathrm{CrN}$ with $\mathrm{B} 1$ structure (face centered cubic) exists. Therefore it is essential to optimize the process parameters for the deposition of stoichiometric cubic $\mathrm{CrN}$ phases. The optimal deposition conditions were determined in our previous study $[4,5]$ and under these conditions, (111) preferred orientation cubic phase of $\mathrm{CrN}$ was obtained (Fig. 1). After optimizing the deposition conditions for $\mathrm{CrN}$ coating, $\mathrm{CrN} / \mathrm{Cr}$ samples were prepared under different deposition conditions of $\mathrm{Cr}$ layers.

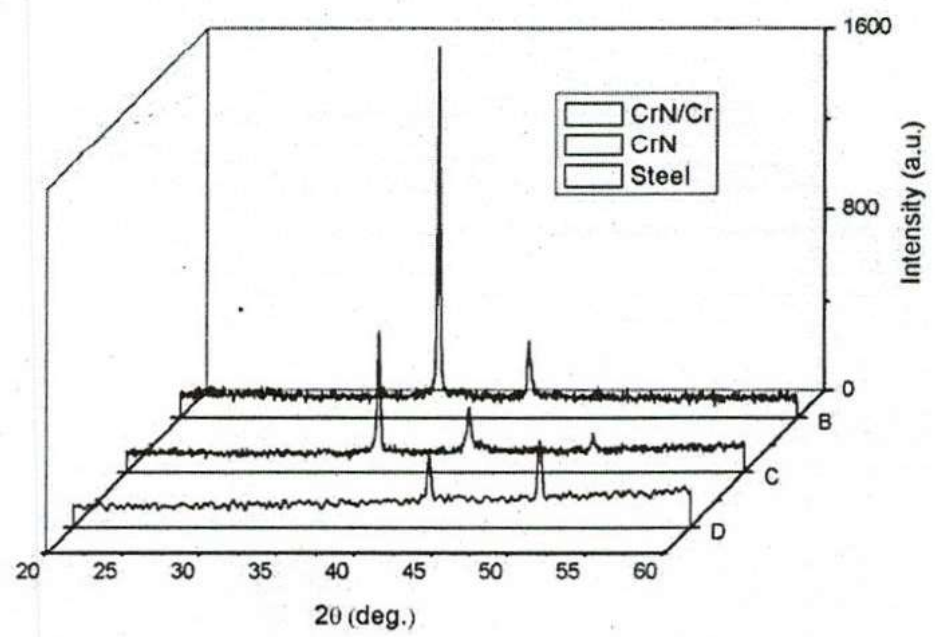

Fig. 1. XRD patterns of steel, $\mathrm{CrN}$ and $\mathrm{CrN} / \mathrm{Cr}$ specimens.

The XRD spectra of $\mathrm{CrN}$ coatings with and without a $\mathrm{Cr}$ interlayer (Fig. 1) are consistent with the JCPDS database of $\mathrm{CrN}$ phase. Both cases have the same preferred orientation of $\mathrm{CrN}$ (111). However, a $\mathrm{Cr}$ layer incorporated between the $\mathrm{CrN}$ coating and the substrate drastically increases (111) peak intensity of the $\mathrm{CrN}$ coating.

The full width at half maximum (FWHM) of the diffraction peak represents the grain size in Scherrer's equation. The FWHMs of the (111) peaks for $\mathrm{CrN}$ and $\mathrm{CrN} / \mathrm{Cr}$ specimens vary slightly from $0.23^{\circ}$ to $0.26^{0}$ so that grain sizes of the $\mathrm{CrN}$ coatings in both cases are similar. 
The $\mathrm{Cr}$ interlayer does not affect the preferred orientation and grain size of the $\mathrm{CrN}$ coatings; this fact is consistent with the authors' previous studies on $\mathrm{Cr}$ interlayer deposited by electroplating and MEVVA (metal vapor vacuum arc) [6,7].

The residual stresses of the $\mathrm{CrN}$ and $\mathrm{CrN} / \mathrm{Cr}$ specimens are evaluated and compared. Residual stresses often exist in deposition coatings and originate from two major sources: one is the intrinsic stress that depends on deposition parameters such as ion bombardment energy, and the other is the thermal stress caused by the different thermal expansion coefficients between the coating and the substrate. Therefore, the residual stress is mainly the intrinsic stress in this case. As shown in the Fig. 1, the (111) diffracted peaks of $\mathrm{CrN}$ coatings with $\mathrm{Cr}$ layers shift towards higher angles, indicating the lower residual stress in the coatings. The residual stresses are calculated experimentally using Eq. (1) for the (111) planes. The calculating results are listed in Table 1 . To our surprise, $\mathrm{Cr}$ interlayer drastically reduces the residual stress in the $\mathrm{CrN}$ coating. The reduction of stress $\Delta \sigma$ can be defined as:

$$
\Delta \sigma=\left|\left(\sigma_{C r N / C r}-\sigma_{C r N}\right) / \sigma_{C r N}\right| \times 100 \%
$$

where $\sigma_{\mathrm{CrN} / \mathrm{Cr}}$ and $\sigma_{\mathrm{Cr}}$ are the corresponding residual stress with and without the $\mathrm{Cr}$ interlayer, respectively.

The above results demonstrate that the role of the $\mathrm{Cr}$ interlayer is apparent: this layer significantly reduces the residual stress of the $\mathrm{CrN}$ coating by up to $36.4 \%$, but it does not affect the preferred orientation and the grain size of the $\mathrm{CrN}$ coating.

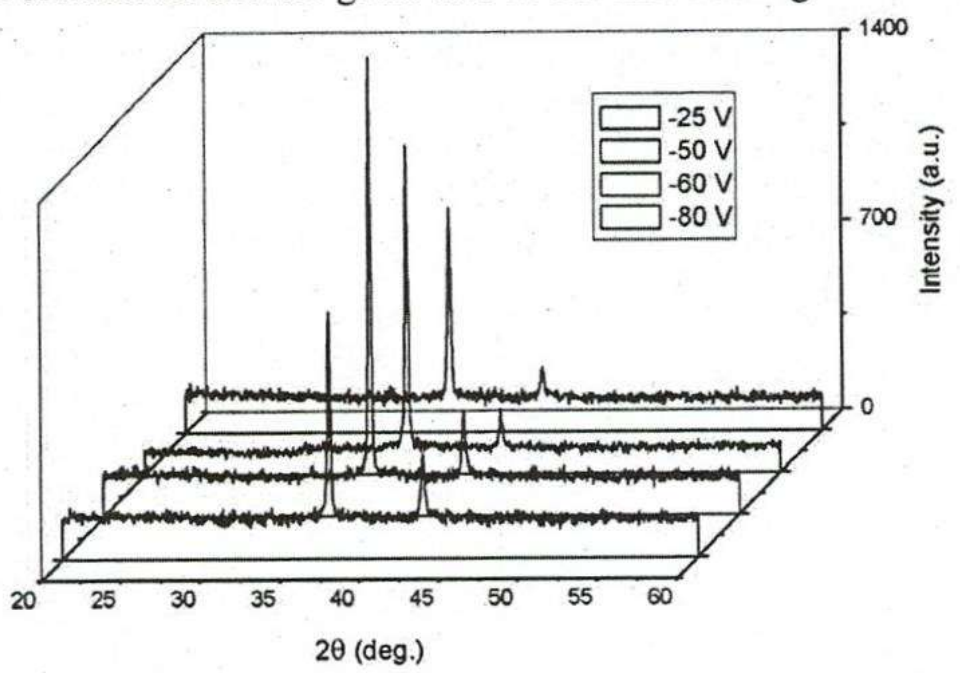

Fig. 2. XRD patterns of $\mathrm{CrN} / \mathrm{Cr}-19\left(\mathrm{~V}_{\mathrm{b}}=-25 \mathrm{~V}\right), \mathrm{CrN} / \mathrm{Cr}-20\left(\mathrm{~V}_{\mathrm{b}}=-50 \mathrm{~V}\right)$, $\mathrm{CrN} / \mathrm{Cr}-21\left(\mathrm{~V}_{\mathrm{b}}=-60 \mathrm{~V}\right), \mathrm{CrN} / \mathrm{Cr}-22\left(\mathrm{~V}_{\mathrm{b}}=-80 \mathrm{~V}\right)$

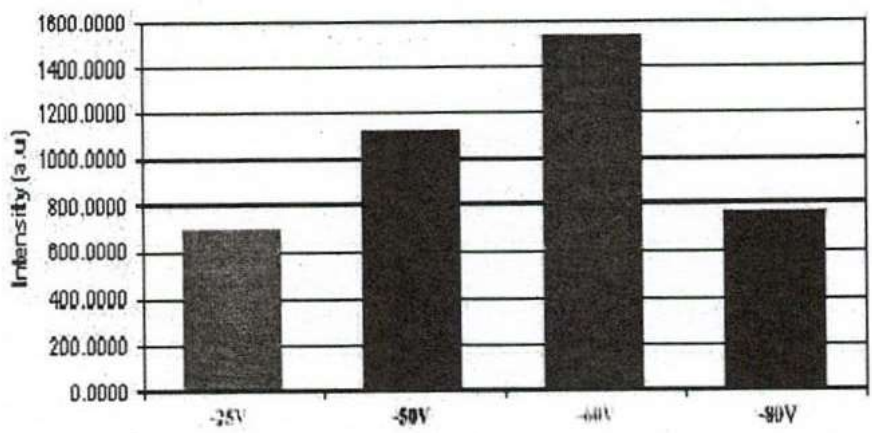

Fig. 3. Substrate bias effects on (111) $\mathrm{CrN}$ diffraction intensity of $\mathrm{CrN} / \mathrm{Cr}$ specimens 
XRD spectra of the $\mathrm{CrN}$ coatings with $\mathrm{Cr}$ layers deposited for various substrate bias of -25 , $-50,-60$, and $-80 \mathrm{~V}$ are compared in order to understand more distinctly the effects of $\mathrm{Cr}$ layers on the crystal structure of $\mathrm{CrN}$ coatings. As shown in Fig. 2, the diffraction patterns of specimens reveal the presence of $\mathrm{CrN}$ cubic phase, and the (111) preferred orientation for the $\mathrm{CrN}$ coatings with the different $\mathrm{Cr}$ layers. However, when the substrate bias is increased from 25 to $-60 \mathrm{~V}$, the intensity of (111) diffraction peaks significantly increases (Fig. 3) and position of the peaks is slightly shifted to higher $2 \theta$ values indicating a reduction in residual stress (Fig. 4). At higher substrate bias $\left(V_{b} \geq-80 \mathrm{~V}\right)$, the intensity (111) peaks decrease. When the substrate bias is below $-60 \mathrm{~V}$, energy and density of the impinging ions bombarded on growing $\mathrm{Cr}$ layer increase, and a better crystallized $\mathrm{Cr}$ layer is then obtained, the structure of $\mathrm{CrN}$ coating grown on this $\mathrm{Cr}$ layer is also better. But as the energy of the impinging ions increases more strongly $\left(\mathrm{V}_{\mathrm{b}} \geq-80 \mathrm{~V}\right)$, re-sputtering occurs and generation of defects in the Cr layer increases, thus (111) peak intensity of the $\mathrm{CrN}$ coating grown on this $\mathrm{Cr}$ layer decreases. Furthermore, reduction of residual stress of the $\mathrm{CrN}$ coatings can be explained by ion bombardment during the coating growth. The $\mathrm{Cr}$ interlayers deposited under different substrate biases affect the (111) peak intensity and the residual stress but do not affect the preferred orientation of the coatings.

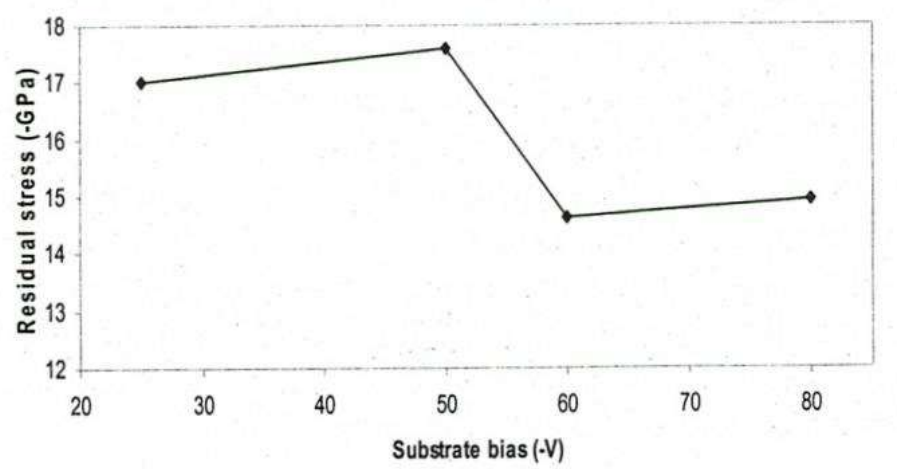

Fig. 4. Residual stress of $\mathrm{CrN}$ coatings as a function of substrate bias

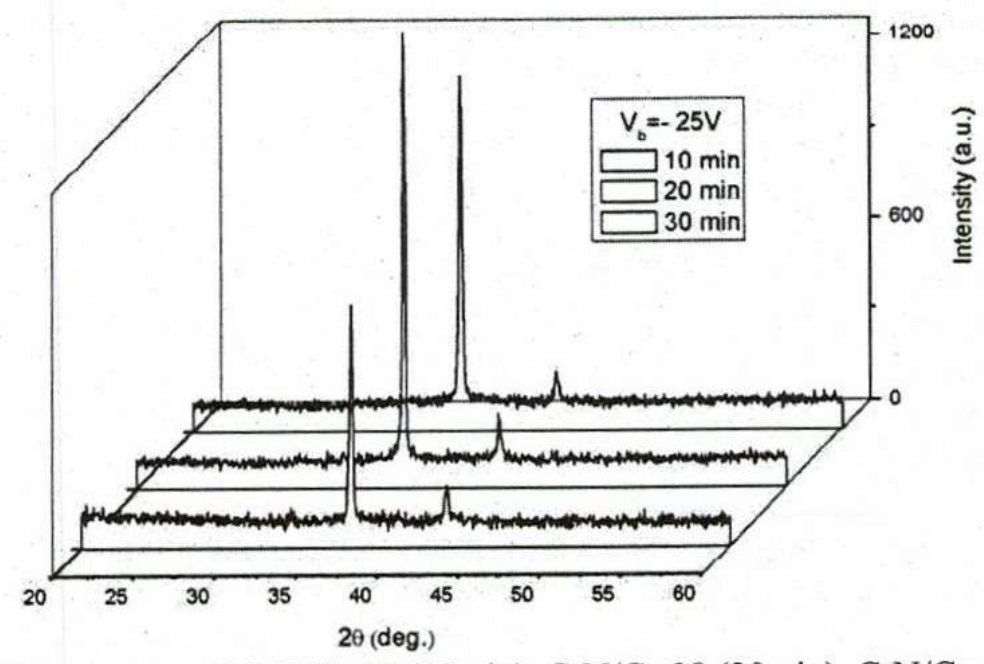

Fig. 5. XRD patterns of CrN/Cr-27 (10min), CrN/Cr-28 (20min), CrN/Cr-19 (30min) 


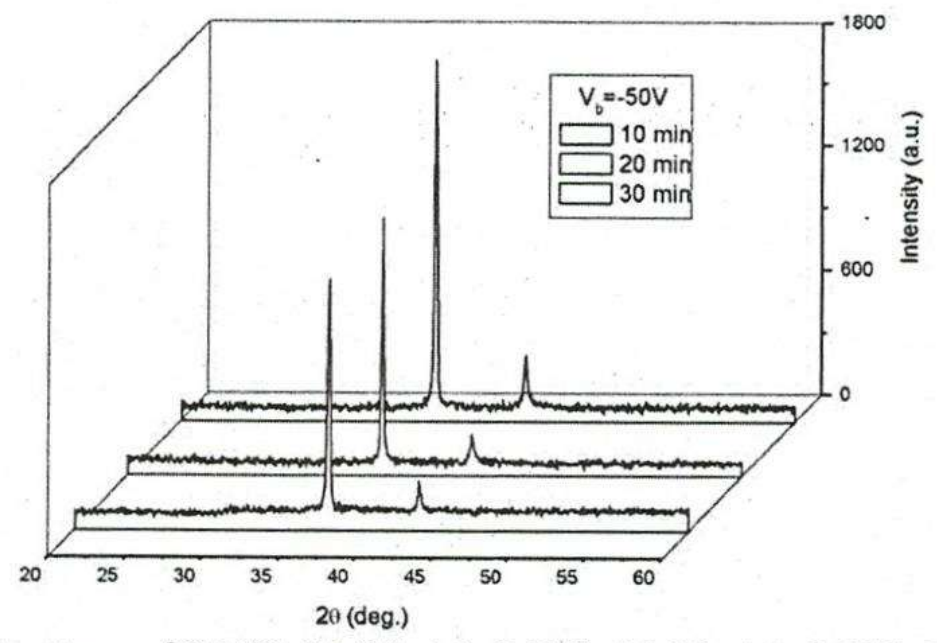

Fig. 6. XRD patterns of $\mathrm{CrN} / \mathrm{Cr}-25$ (10min), $\mathrm{CrN} / \mathrm{Cr}-24$ (20min), $\mathrm{CrN} / \mathrm{Cr}-20$ (30min)

Also, similar phenomenons are observed with the variation of deposition time of $\mathrm{Cr}$ interlayers. The XRD spectra of the $\mathrm{CrN}$ coatings with different deposition time of $\mathrm{Cr}$ layers $(10,20$ and $30 \mathrm{~min}$ ) at substrate biases of $-25 \mathrm{~V}$ (Fig. 5) and -50V (Fig. 6) show that deposition time of $\mathrm{Cr}$ layers does not vary the (111) preferred orientation of $\mathrm{CrN}$ coatings. The intensity of this (111) peak is maximum when deposition time is 20 minutes in the case of $\mathrm{V}_{\mathrm{b}}=-25 \mathrm{~V}$, and 10 minutes when $\mathrm{V}_{b}=-50 \mathrm{~V}$. Thus there is a certain value of thickness of $\mathrm{Cr}$ layer that lead to the formation of the best crystal structure of $\mathrm{CrN}$ coating. As mentioned above, this value of $\mathrm{Cr}$ layer can be found at the deposition time of 20 minutes at $\mathrm{V}_{\mathrm{b}}=-25 \mathrm{~V}$ and $10 \mathrm{~min}$ at $\mathrm{V}_{\mathrm{b}}=$ $50 \mathrm{~V}$. The energy and density of the impinging ions bombarded on the growing $\mathrm{Cr}$ layer increase proportionally to the substrate bias. So the higher substrate bias is, the sooner the $\mathrm{Cr}$ layers reach this ideal thickness. It may be concluded that the thickness of the $\mathrm{Cr}$ interlayer also influences the crystal structure of the $\mathrm{CrN}$ coating.

\subsection{Electrochemical behavior}

The corrosion resistance of $\mathrm{CrN} / \mathrm{Cr}$ is compared with that of $\mathrm{CrN}$ and bare steel. The polarization curves of potential (relative to sce) vs. current density are shown in Fig. 7 and Fig. 8. Corrosion potentials of specimens are listed in Table 1.

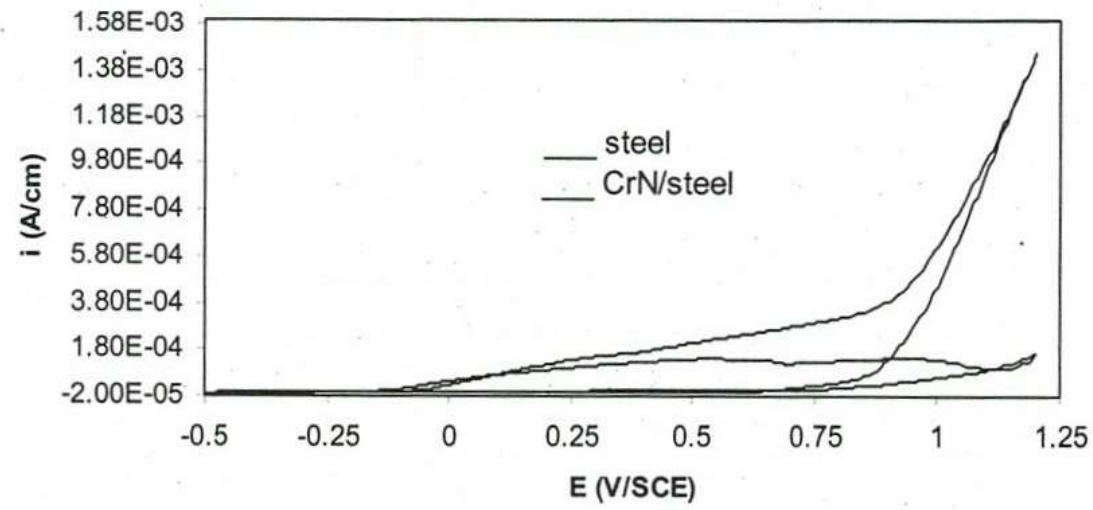

Fig. 7. Polarisation curves of steel and $\mathrm{CrN} / \mathrm{steel}$ in $3.5 \% \mathrm{NaCl}$ solution 


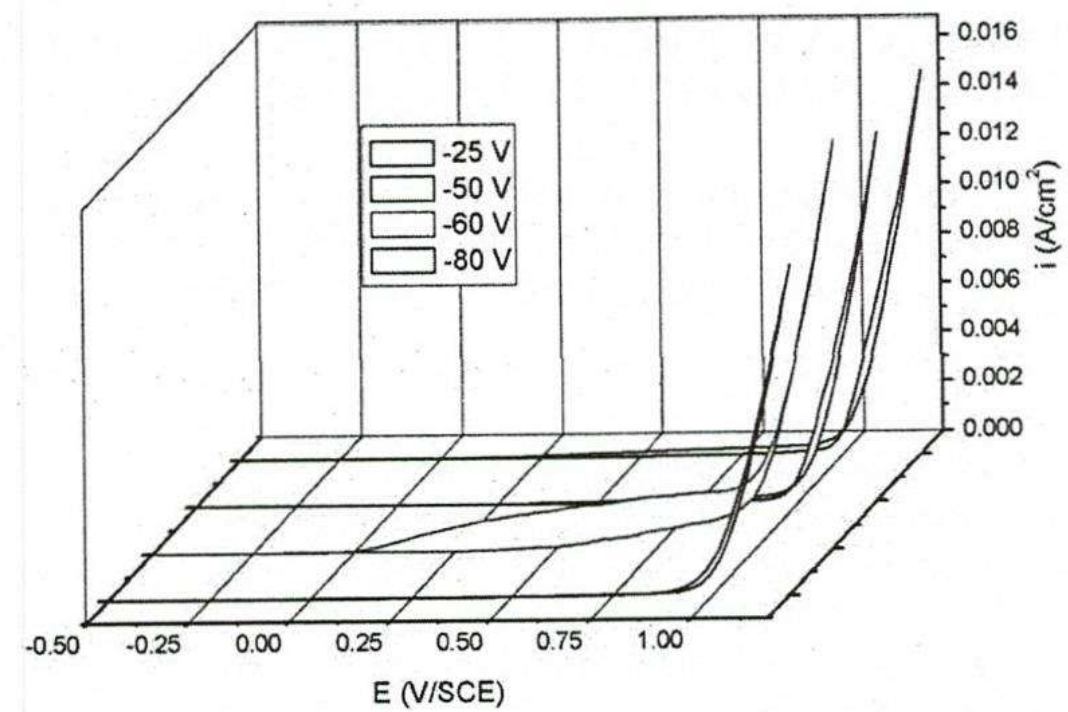

Fig. 8. Polarisation curves of $\mathrm{CrN} / \mathrm{Cr}-19$ (-25V), $\mathrm{CrN} / \mathrm{Cr}-20$ (-50V), $\mathrm{CrN} / \mathrm{Cr}-21$ (-60V), $\mathrm{CrN} / \mathrm{Cr}-22(-80 \mathrm{~V})$

The $\mathrm{E}_{\text {corr }}$ value of $\mathrm{CrN}(0.86 \mathrm{~V} / \mathrm{sce})$ is significantly higher than that of bare steel $(0.58 \mathrm{~V} / \mathrm{sce})$, indicating that the $\mathrm{CrN}$ coating deposited steel surface improves the corrosion resistance. The $\mathrm{E}_{\text {corr }}$ of $\mathrm{CrN}$ specimen decreases more than that of $\mathrm{CrN} / \mathrm{Cr}$ specimen $(\sim$ $0.98 \mathrm{~V} / \mathrm{sce})$, showing that $\mathrm{CrN} / \mathrm{Cr}$ possesses a better capability of preventing the localized galvanic attack between the coating and the substrate. The performance of the coated steels against corrosion is strongly affected by defects of the coating [3]. The Cr layer promotes the surface passivity of the steel substrate and isolates physically the structure defects of the $\mathrm{CrN}$ coatings. It may be concluded from these observations that the $\mathrm{Cr}$ layer in $\mathrm{CrN} / \mathrm{Cr} / \mathrm{steel}$ provides a beneficial effect on the corrosion resistance of the steel.

Fig. 8 shows polarization curves of $\mathrm{CrN} / \mathrm{Cr}$ specimens with $\mathrm{Cr}$ interlayers deposited for various substrate bias of $-25,-50,-60$, and $-80 \mathrm{~V}$. The polarization curves and $\mathrm{E}_{\text {corr }}$ values of specimens indicate that despite diffirent $\mathrm{Cr}$ interlayers, the corrosion resistance of all $\mathrm{CrN} / \mathrm{Cr} /$ steel specimens is similar. The $\mathrm{Cr}$ interlayer effectively reduces the corrosion, but this corrosion resistance does not change when altering the $\mathrm{Cr}$ interlayer. Thus electrochemical behavior of coated steel seems to be controled by the outer layer.

\section{CONCLUSIONS}

In this study, $\mathrm{CrN}$ coatings with and without the $\mathrm{Cr}$ interlayers are successfully synthesized using d.c. magnetron sputtering (for $\mathrm{Cr}$ layers) and reactive d.c. magnetron sputtering (for $\mathrm{CrN}$ layers). the $\mathrm{CrN}$ coatings have only $\mathrm{CrN}$ cubic phase with (111) preferred orientation in both case without and with the different $\mathrm{Cr}$ interlayers. Although the $\mathrm{Cr}$ interlayer does not affect the grain size of $\mathrm{CrN}$, it significantly reduces the residual stress of the $\mathrm{CrN}$ coating by up to $36.4 \%$ and increases the corrosion resistance of the $\mathrm{CrN}$ coating. When increasing the substrate bias of the $\mathrm{Cr}$ interlayers from $-25 \mathrm{~V}$ to $-60 \mathrm{~V}$, the crystal structures of the $\mathrm{CrN}$ coatings are better, the residual stresses of the $\mathrm{CrN}$ coatings decrease but the corrosion resistance does not change. The higher substrate bias of $\mathrm{Cr}$ interlayer is, the sooner $\mathrm{Cr}$ interlayer reach the ideal thickness which induces the best crystal structure of $\mathrm{CrN}$ coating. 


\title{
ẢNH HƯỞNG CỦA LỚP ĐỂM Cr LÊN CÂU TRÚC TINH THỂ VÀ ĐỘ CHỐNG ĂN MÒN CỦA MÀNG CrN PHỦ TRÊN ĐẾ INOX
}

\author{
Đinh Thị Mộng Cầm, Nguyễn Thanh Phương, Nguyễn Thế Quyền, \\ Nguyễn Hữu Chí, Lề Khắc Bình, Trần Tuấn, Dương Ái Phương, Nguyễn Chi Lăng \\ Trường Đại học Khoa học Tự nhiên, ĐHQG-HCM
}

\begin{abstract}
Tóm tắt: Trong các nghiên cưu trước, chúng tôi đã chế tạo thành công màng CrN phủ trục tiếp trên đế inox. Màng tạo ra có độ cứng cao và có úng dụng cu thể trong thục tế. Tuy nhiên độ bám dính của màng trên đế inox cần được cải thiện. Trong báo cáo này, chúng tôi tiến hành tổng hợp màng cứng $\mathrm{CrN}$ trên đế inox có lớp đệm $\mathrm{Cr}$ để gia tăng độ bám dính của màng. Màng $C r N$ và lớp đệm $C r$ đều được tạo bằng phuơng pháp phún xạ magnetron và ló́p Cr được phủ tại nhiều điều kiện khác nhau để khảo sát sụ ảnh hưởng của nó lên cấu trúc và độ chống ăn mòn của màng $C r N$. Kết quả khảo sát cho thấy màng CrN phủ trực tiếp trên đế inox và phủ trên lớp inox có lớp đệm $\mathrm{Cr}$ đều xuất hiện một pha duy nhất thuộc cấu trúc lập phương tâm mặt với định hướng ư tiên theo mặt (111) song song với bề mặt màng và kích thước hạt của CrN trong hai trường hợp không thay đổi. Tuy nhiên, nếu màng CrN phủ trên inox có lớp Cr ở giũ̃a thi cuờng độ đỉnh phổ (111) tăng lên đáng kể, úng suất nén của màng $C r N$ giảm đến $36.4 \%$ và độ chổng ăn mòn của màng tăng. Hơn nũa, có sụ thay đổi cuờng độ đỉnh (111) và úng suất của màng CrN khi phủ trên lớp Cr được tạo ở các thế hiệu dịch và thời gian khác nhau, mặc dù độ chống ăn mòn của các màng CrN thì tương tụ nhau. Khi lớp $\mathrm{Cr}$ được tạo với thời gian dưới 10 phút và thế hiệu dịch $-60 \mathrm{~V}$ thì màng $\mathrm{CrN} / \mathrm{Cr}$ có cấu trúc tinh thể và khả năng bảo vệ tốt nhất.
\end{abstract}

Tù̀ khóa: Màng cúng $C r N$, màng $C r N / C r$, phún xạ phản úng magnetron d.c.

\section{REFERENCES}

[1]. Hong-Ying Chen, Sheng Han, Han C. Shih, Materials Letters, 58, 2924 (2004).

[2]. S. Han, H.Y. Chen, Z.C. Chang, K.W. Weng, D.Y. Wang, F.H. Lu, H.C. Shih, Thin Solid Films, 447-448, 425 (2004).

[3]. K.L. Chang, S. Han, J.H. Lin, J.W. Hus, H.C. Shih, Surf. Coat. Technol., 172, 72-78 (2003).

[4]. Dinh Thi Mong Cam, Master of Science Thesis, 2008.

[5]. Dinh Thi Mong Cam, Nguyen Huu Chi, Le Khac Binh, Tran Tuan, Nguyen Thi Hai Yen, Tran Quang Trung, Science \& Technology Development, Vol. 10, 5 (2007).

[6]. S. Han, J.H. Lin, X.J. Guo, S.H. Tsai, Y.O. Su, J.H. Huang, F.H. Lu, H.C. Shih, Thin Solid Films, 377-378, 578 (2000).

[7]. S. Han, H.Y. Chen, Z.C. Chang, J.H. Lin, C.J. Yang, F.H. Lu, F.S. Shieu, H.C. Shih, Thin Solid Films, 436, 238 (2003). 